\title{
Vitamin D status among adults in the Aegean region of Turkey
}

\author{
Zeliha Hekimsoy ${ }^{1 *}$, Gönül Dinç², Sabriye Kafesçiler ${ }^{1}$ Ece Onur ${ }^{3}$, Yesim Güvenç ${ }^{4}$, Tümer Pala $^{5}$, Feyzullah Güçlü , \\ Bilgin Özmen ${ }^{1}$
}

\begin{abstract}
Background: Vitamin D is a lipid-soluble hormone found in certain foods and synthesized from precursors in the skin when exposed to ultraviolet light. Vitamin D plays a critical role in bone metabolism and many cellular and immunological processes and low levels have been associated with several chronic and infectious diseases. Vitamin $D$ status is assessed by measuring the concentration of serum 25-hydroxyvitamin $D[25(\mathrm{OH}) \mathrm{D}]$. Vitamin $\mathrm{D}$ deficiency is reported to be common worldwide, but little has been reported about the vitamin D status of adults in Turkey. In this cross-sectional study, we determined the prevalence of $25(\mathrm{OH}) \mathrm{D}$ deficiency in adults residing in a city in the Aegean region of Turkey.

Methods: A survey was conducted on a representative sample of adults over 20 years old in a non-coastal city at the end of the winter season. Of the 209 households selected by random sampling, 8.6\% ( $n=18)$ were unoccupied and $21.5 \%(n=45)$ refused to participate. Blood samples were taken and questions about medical history, vitamin supplementation, sunlight exposure, and dietary calcium and vitamin D intake were asked in faceto-face interviews of 391 adults living in the remaining households.

Results: The mean serum 25(OH)D concentration was $16.9 \pm 13.09 \mathrm{ng} / \mathrm{mL}$, with $74.9 \%$ of the subjects having $25(\mathrm{OH}) \mathrm{D}$ deficiency $(<20 \mathrm{ng} / \mathrm{mL}), 13.8 \%$ having insufficiency $(20-29.99 \mathrm{ng} / \mathrm{mL})$, and $11.3 \%$ of the subjects having sufficient $25(\mathrm{OH})$ $\mathrm{D}(\geq 30 \mathrm{ng} / \mathrm{mL}$ ) levels. 25(OH)D deficiency was more common among females $(78.7 \%)$ than males $(66.4 \%, \mathrm{p}<0.05)$.
\end{abstract}

Conclusion: Adults living in an urban, non-coastal setting in Turkey have a high prevalence of vitamin $D$ deficiency.

\section{Background}

Vitamin D is a lipid-soluble hormone found in certain foods and synthesized from precursors in the skin when exposed to ultraviolet light [1-10]. Vitamin D plays a critical role in bone metabolism and many cellular and immunological processes; and low levels have been associated with several chronic and infectious diseases including diabetes [11-13], cardiovascular diseases [6], cancer [14-17], multiple sclerosis [18,19], osteoporosis [9], autoimmune diseases [20], and microbial infections [21]. Vitamin D deficiency is generally due to a lack of adequate sunlight exposure or excessive use of sunscreen, and/or inadequate nutritional vitamin D intake [10]. Tropospheric ozone, a common pollutant in central urban areas, is also associated with

\footnotetext{
* Correspondence: zhekimsoy@hotmail.com

'Celal Bayar University Medical Faculty, Department of Internal Medicine,

Division of Endocrinology and Metabolism, Manisa, Turkey

Full list of author information is available at the end of the article
}

reduced synthesis of vitamin $\mathrm{D}$ in the skin and resulting vitamin D deficiency [22]. Several other factors such as skin pigmentation, age, weight, malabsorption disorders and disorders that affect vitamin D metabolism can also affect vitamin D concentrations [1-10]. Plasma (or serum) 25(OH)D is currently the best indicator for vitamin D status (1). This is a measure of the circulating concentration of serum $25(\mathrm{OH}) \mathrm{D}$, which reflects vitamin $\mathrm{D}$ from all sources: cutaneous synthesis, diet and supplements [1,9].

Although there is no consensus on optimal serum levels of $25(\mathrm{OH}) \mathrm{D}$, vitamin $\mathrm{D}$ deficiency is defined by most experts as a level less than $20 \mathrm{ng} / \mathrm{mL}$ [1]. Vitamin $\mathrm{D}$ deficiency is a highly prevalent condition, present in approximately $30 \%$ to $50 \%$ of the general population [6]. This worldwide pandemic remains generally unrecognised and untreated. To date, little has been reported about the vitamin D status of adults in Turkey [23-26]. In this cross-sectional study, we determined the
C Biomed Central

(c) 2010 Hekimsoy et al; licensee BioMed Central Ltd. This is an Open Access article distributed under the terms of the Creative Commons Attribution License (http://creativecommons.org/licenses/by/2.0), which permits unrestricted use, distribution, and reproduction in any medium, provided the original work is properly cited. 
prevalence of vitamin D deficiency in adults residing in a city in the Aegean region of Turkey.

\section{Methods Setting}

This cross-sectional study was conducted in the city of Manisa $\left(38.36^{\circ} \mathrm{N}\right.$ latitude), a non-coastal city in the Aegean region of Turkey with a population of 303,155 [27]. The population was $55 \%$ urban, $30 \%$ semiurban and $15 \%$ rural. Clothing covering the whole body (face included), while common in some countries (eg. burqa), is very rarely worn in western Turkey. The study protocol was approved by the Institute of Health and Human Development Ethical Issues on Clinical Trials Review Board of Celal Bayar University.

In 2007, when the data was collected, the winter was drier and sunnier than normal. The average duration of sunlight in this region is 0 to 9 hours per day in winter and 0.30 to 11 hours per day in summer. The minimum and maximum temperatures of this region range from $-2.4^{\circ}$ to $19.7^{\circ} \mathrm{C}$ in winter and $15^{\circ}$ to $45^{\circ} \mathrm{C}$ in summer.

\section{Study sample}

The study sample was selected from among a population of 205,940 persons over 20 years old who granted consent to participate in the study. Exclusion criteria consisted of a history of liver disease, renal failure, or cancer, or calcium or vitamin D supplement use or the presence of a parathyroid problem $(n=0)$. Using an estimated prevalence of vitamin D deficiency in the population of $30 \%(\mathrm{p})$, and accepting a 5\% type 1 error, the sample size needed to reach a power of $80 \%$ with a precision of $4 \%$ (s) in reporting the prevalence of vitamin D deficiency was calculated to be 504 individuals.

$$
\mathrm{n}=\frac{\mathrm{p}(1-\mathrm{p}) \mathrm{t}_{0.05}}{\mathrm{~s}^{2}}=\frac{(0.30) \times(0.70) \times(1.96)^{2}}{(0.04) \times(0.04)}=504 \text { individuals }
$$

During the study period, the primary health care system of Turkey covered the whole population, and was organized through health center districts. Sample groups were selected randomly from records of households of three different primary health centers (urban/semiurban/rural) using systematic sampling methods. The number of households for each neighborhood were determined according to neighborhood's proportional population in the city and the neighborhood's mean household size over 20 years (2.4 persons per household, according to official records). Overall, 209 households were randomly selected, and adults convenient for participation in the study were asked to participate, ie. some households had more than one adult participate in the study.

\section{Data collection}

The data were collected in the winter, in February of 2007. A structured questionnaire (previously tested for comprehension on 10 women and 10 men who were in the hospital for ambulatory care) was answered during face-to-face interviews with the study population in their homes. Demographic data was collected, as well as information concerning the family's socio-economical level, age, gender, occupation, family income, highest educational level, chronic diseases, medications, dietary intake of calcium and vitamin $\mathrm{D}$, and habits and clothing which preclude exposure to sunlight (see below). Weight and height were directly measured, from which body mass index (BMI, $\mathrm{kg} / \mathrm{m}^{2}$ ) was calculated.

Ten $\mathrm{mL}$ of blood was collected from a peripheral vein, quickly placed on ice, and transported to the laboratory where it was centrifuged at $4000 \mathrm{rpm}$ for four minutes, then serum and plasma were stored at $-70^{\circ} \mathrm{C}$ until analysis. Serum was tested for the following biochemical parameters: $25(\mathrm{OH}) \mathrm{D}$, parathyroid hormone $(\mathrm{PTH})$, calcium, phosphorus, alkaline phosphatase, creatinine and albumin.

\section{Biochemical parameters}

PTH levels were measured by chemiluminescence method on an IMMULITE $2000^{\circ}$ analyzer (Diagnostic Products Corporation, Los Angeles, USA). 25(OH)D levels were measured by HPLC (Thermo-Finnigan, Waltham, USA) using Vitamin D3 ClinRep HPLC kits (RECIPE Chemicals+Instruments GmbH, Munich, Germany). The method involves a $50 \mu \mathrm{L}$ injection volume of the sample in a mobile phase which has a flow rate of $1.0 \mathrm{~mL} /$ minute. Measurements are calculated by using internal standard-methods via peak areas. For the determination of the within-run precision, the samples were measured in duplicate. The average coefficient of variation was $4.8 \%$. Since the measurements were done on the same day, intra-assay precision was not calculated. However, the manufacturer claims a $2.3-4.9 \%$ coefficient of variation for a concentration of $21.1 \mu \mathrm{g} / \mathrm{L}$.

\section{Terms and definitions}

\section{Assessment of exposure to sunlight}

We did not directly measure exposure to sunlight. On the questionnaire, the interviewer asked about being inside between 10 a.m. and 4 p.m, wearing of a hat or long-sleeve shirts/skirts when outside, and use of sunscreen and/or an umbrella when outside. A Likert scale was used for each question: always (1 point), usually ( 2 points), sometimes (3 points), and never (4 points). Adding up the points for these questions gave us a 'sun exposure index' ranging from a low of 4 points to a maximum of 16 points. Sun exposure was considered mild ( $<8$ points), moderate (8-11 points) or high (12-16 
points). Regular wearing of clothing limiting exposure to sunlight was also asked, as a yes/no question. 'Yes' was recorded if usually the person wore clothing which allowed for only the face and hands to be exposed to the sun. If otherwise, 'no' was recorded.

\section{Vitamin D status}

Vitamin D nutritional status was assessed as deficient if $25(\mathrm{OH}) \mathrm{D}$ levels were $<20 \mathrm{ng} / \mathrm{mL}$, insufficient if between 20 and $30 \mathrm{ng} / \mathrm{mL}$, and sufficient if $\geq 30 \mathrm{ng} / \mathrm{mL}$ [1].

\section{Other}

Mean daily calcium intake was determined according to the daily diet history. Present medical problems and medications were elicited by the interviewer.

\section{Statistical analyses}

All statistical analyses were performed using SPSS for Windows $^{\oplus} 11.0$ (SPSS, Inc. Chicago, USA). Chi-square test and Student's t test were used for bivariate analysis. Two logistic regression models were developed to examine the associations between vitamin D levels and risk factors. The adjusted odds ratios and their corresponding 95\% confidence intervals (CIs) were calculated. Sex (male/female), age ( $<50$ or $\geq 50$ years), clothing limiting exposure to sunlight (Yes/No), and area of residence (urban/semiurban/rural) were included as potential confounders in the multivariate analysis. Independent variables (age, sex, wearing of clothing which limits exposure to sunlight, and household location) were compared by logistic regression in patients with various levels of vitamin $\mathrm{D}$, using two different models: vitamin $\mathrm{D}$ deficiency or insufficiency vs sufficiency (Model I) and vitamin D deficiency vs. sufficiency (Model II). P values less than 0.05 were regarded as statistically significant.

\section{Results}

Of the 209 randomly selected households, $8.6 \%(\mathrm{n}=18)$ were unoccupied and $21.5 \%(n=45)$ of the households refused an interview. Thus the overall rate of participation was $70 \%$ (64\% in urban, $89 \%$ in semiurban, and $53 \%$ in rural areas). Thus, households from the semiurban neighborhoods were overrepresented in our population sample.

We enrolled 391 subjects in the study (mean age 45.11 \pm 17.28 years $): 30.4 \%$ male $(n=119$, mean age $45.05 \pm$ 17.47 years), $69.6 \%$ female $(n=272$, mean age $45.13 \pm$ 17.23 years), and $62.7 \%$ were less than 50 years old. Of the participants, $39.6 \%$ were from urban, $49.4 \%$ from semiurban, and $11.0 \%$ from rural areas (Table 1). No patient was taking calcium or vitamin $\mathrm{D}$ as a supplement. None had a parathyroid problem, chronic kidney disease, liver disease or other medical conditions which might affect vitamin $\mathrm{D}$ metabolism.

Overall, $67.6 \%$ of the respondents regularly wore clothing that prevented exposure to sunlight $(72.6 \%$ in women, $55.8 \%$ in men, $\mathrm{p}<0.001$, Table 1 ). Regarding the sun exposure index, $4.5 \%$ had mild, $43.8 \%$ had medium, and $51.7 \%$ had high exposure to sunlight. Women had less exposure to sunlight than men $(\mathrm{p}<0.001$, Table 1). Calcium intake was low in the respondents (Table 1).

The overall mean $25(\mathrm{OH}) \mathrm{D}$ level was $16.91 \pm 13.09$ $\mathrm{ng} / \mathrm{mL}$; levels were lower in women than in men $(15.25$ $\pm 11.53 \mathrm{ng} / \mathrm{mL}$ vs $20.70 \pm 15.50 \mathrm{ng} / \mathrm{mL}$, respectively, $\mathrm{p}$ $=0.001$, Student's t test, Table 1$) .25(\mathrm{OH}) \mathrm{D}$ status was not significantly different when analyzed according to age, BMI, and area of residence (Table 2). Overall, $74.9 \%$ had vitamin D deficiency, $13.8 \%$ had vitamin D insufficiency, and only $11.3 \%$ had sufficient levels of vitamin D. Vitamin D deficiency was significantly more common among women $(78.7 \%)$ than men $(66.4 \%$, $\mathrm{p}<0.01) .25(\mathrm{OH}) \mathrm{D}$ levels were not significantly different in persons according to age, BMI, or household location.

25(OH)D levels according to style of dress and sunlight exposure are given in Table 3 . Those wearing clothing which restricted exposure to sunlight were more likely to have vitamin D deficiency $(77.2 \%)$ than those who wore clothing which allowed more sunlight exposure $(71.3 \%)$. In the same way, those wearing clothing which restricted exposure to sunlight were more likely to have vitamin D insufficiency (14.6\%) than those who wore clothing which allowed more sunlight exposure $(11.5 \%, p=0.032$, Table 3$)$. However, sunlight exposure, as measured by our scale, and daily calcium intake, were not significantly associated with 25(OH)D status.

Results of the logistic regression models are presented in Table 4. Those who regularly wore clothing which restricted skin exposure to sunlight were more likely to have vitamin D deficiency or insufficiency (Table 4). The odds of being vitamin $\mathrm{D}$ deficient was over two times as high for those living in urban areas compared to semiurban areas (Table 4).

\section{Discussion}

Vitamin D deficiency is being increasingly recognised worldwide [1,9]. Studies among those living in Turkey have been few, and most have been performed among women, those in nursing homes, and the elderly [23-26]. To date, no study has examined vitamin $\mathrm{D}$ status in a population based sample in Turkey. This is the first such study, and found quite a high prevalence of vitamin D deficiency (74.9\%) and insufficiency (13.8\%), quite a high proportion for an area of the country which gets lots of sunlight.

Other reports in the literature have found vitamin $\mathrm{D}$ deficiency (as defined by a 25(OH)D level of less than $<20 \mathrm{ng} / \mathrm{mL}$ ) in $40-100 \%$ of those tested, with proportions varying according to geographic area, latitude and 
Table 1 Demographic characteristics, sunlight exposure, reported calcium intake, and mean 25(OH)D levels of the participants

\begin{tabular}{|c|c|c|c|c|}
\hline & Male $(n=119)$ & Female $(n=272)$ & Total $(n=391)$ & $\mathbf{P}$ \\
\hline Total & $30.4 \%$ & $69.6 \%$ & $100.0 \%$ & \\
\hline Age & & & & ${ }^{*} p=0.6$ \\
\hline$<50$ years & $62.4 \%$ & $62.9 \%$ & $62.7 \%$ & \\
\hline$\geq 50$ years & $37.6 \%$ & $37.1 \%$ & $37.3 \%$ & \\
\hline Area of residence & & & & ${ }^{*} p=0.1$ \\
\hline Urban & $46.2 \%$ & $36.8 \%$ & $39.6 \%$ & \\
\hline Semi-urban & $45.4 \%$ & $51.1 \%$ & $49.4 \%$ & \\
\hline Rural & $8.4 \%$ & $12.1 \%$ & $11.0 \%$ & \\
\hline Wearing clothes which restrict exposure to sunlight & & & & ${ }^{*} p=0.001$ \\
\hline Yes & $55.8 \%$ & $72.6 \%$ & $67.6 \%$ & \\
\hline No & $44.2 \%$ & $27.4 \%$ & $32.4 \%$ & \\
\hline Sunlight exposure index & & & & ${ }^{*} p=0.0009$ \\
\hline$<8$ points & $0.9 \%$ & $6.1 \%$ & $4.5 \%$ & \\
\hline 8-11 points & $30.4 \%$ & $49.6 \%$ & $43.8 \%$ & \\
\hline$\geq 12$ points & $68.7 \%$ & $44.3 \%$ & $51.7 \%$ & \\
\hline Daily calcium intake & & & & ${ }^{*} p=0.8$ \\
\hline 500 mg/day & $19.3 \%$ & $20.2 \%$ & $19.9 \%$ & \\
\hline$<500$ mg/day & $80.7 \%$ & $79.8 \%$ & $80.1 \%$ & \\
\hline Mean \pm SD 25(OH)D level $(\mathrm{ng} / \mathrm{mL})$ & $20.70 \pm 15.50$ & $15.25 \pm 11.53$ & $16.91 \pm 13.09$ & $* * p=0.001$ \\
\hline
\end{tabular}

${ }^{*}$ Chi-square testing.

**Student's $t$ test.

Table 2 Vitamin D status and age, gender, body mass index (BMI) and area of residence

\begin{tabular}{|c|c|c|c|c|}
\hline & \multicolumn{3}{|c|}{$\begin{array}{l}25(\mathrm{OH}) \mathrm{D} \\
\text { status }\end{array}$} & \multirow[b]{2}{*}{$p^{*}$} \\
\hline & $\begin{array}{l}\text { Deficient } \\
(<20 \mathrm{ng} / \\
\mathrm{mL})\end{array}$ & $\begin{array}{l}\text { Insufficient } \\
(20-29.99 \mathrm{ng} / \\
\mathrm{mL})\end{array}$ & $\begin{array}{l}\text { Sufficient } \\
(\geq 30 \mathrm{ng} / \\
\mathrm{mL})\end{array}$ & \\
\hline Total $(n=391)$ & $74.9 \%$ & $13.8 \%$ & $11.3 \%$ & \\
\hline Age (years) (n) & & & & $p=0.6$ \\
\hline$<50(\mathrm{n}=247)$ & $75.7 \%$ & $14.2 \%$ & $10.1 \%$ & \\
\hline$\geq 50(n=144)$ & $73.6 \%$ & $13.2 \%$ & $13.2 \%$ & \\
\hline Gender & & & & $p=0.025$ \\
\hline Male $(\mathrm{n}=119)$ & $66.4 \%$ & $20.2 \%$ & $13.4 \%$ & \\
\hline Female $(n=272)$ & $78.7 \%$ & $11.0 \%$ & $10.3 \%$ & \\
\hline BMI $\left(\mathrm{kg} / \mathrm{m}^{2}\right)$ & & & & $p=0.9$ \\
\hline$<25(n=151)$ & $74.0 \%$ & $14.0 \%$ & $12.0 \%$ & \\
\hline $\begin{array}{l}25-29.99 \\
(n=152)\end{array}$ & $74.3 \%$ & $15.8 \%$ & $9.9 \%$ & \\
\hline$\geq 30(n=88)$ & $69.0 \%$ & $19.0 \%$ & $12.1 \%$ & \\
\hline $\begin{array}{l}\text { Area of } \\
\text { residence }\end{array}$ & & & & $p=0.07$ \\
\hline $\begin{array}{l}\text { Semiurban }(n= \\
193)\end{array}$ & $70.5 \%$ & $14.5 \%$ & $15.0 \%$ & \\
\hline Urban $(n=155)$ & $76.8 \%$ & $14.8 \%$ & $8.4 \%$ & \\
\hline Rural $(n=43)$ & $88.4 \%$ & $7.0 \%$ & $4.7 \%$ & \\
\hline
\end{tabular}

${ }^{*}$ Chi-square test. specifics of the patient population [1,28-30]. The Third National Health and Nutrition Examination Survey (NHANES III) reported the prevalence of vitamin D deficiency in the U.S.A. to be between $25 \%$ and $57 \%$ of adults [28]. Van der Wielen et al. [29] measured wintertime serum 25-hydroxyvitamin D concentrations in 824 elderly people from 11 European countries and found vitamin D levels lower than $20 \mathrm{ng} / \mathrm{mL}$ in $36 \%$ of men and $47 \%$ of women. Surprisingly, vitamin D deficiency was much more common in people living in sunny countries such as Italy, Spain and Greece than among those living in Scandinavian countries where sunlight exposure is less. Higher fish consumption and vitamin D fortification of food could explain this difference [29].

The mean 25(OH)D level was low $(16.91 \pm 13.09 \mathrm{ng} /$ $\mathrm{mL}$ ) in our study population. As in other studies [23,26,30-32], vitamin D deficiency was more common in women than in men $(78.7 \%$ vs $66.4 \%)$ and mean 25 $(\mathrm{OH}) \mathrm{D}$ levels in women were significantly lower than in men. Kull et al. [33] reported mean wintertime $25(\mathrm{OH})$ D levels to be $17.2 \pm 5.9 \mathrm{ng} / \mathrm{mL}$ in the general population of Estonia (latitude $59^{\circ} \mathrm{C}$ ). The prevalence of vitamin D deficiency in their study was $8 \%$ and insufficiency $73 \%$, which are slightly lower than in our population, although Estonia is located much farther north and receives less sunlight than the Aegean region of Turkey. 
Table 3 Vitamin D status and clothing, sunlight exposure and calcium levels

\begin{tabular}{|c|c|c|c|c|}
\hline & \multicolumn{3}{|c|}{$25(\mathrm{OH}) \mathrm{D}$ status } & \multirow[b]{2}{*}{$\mathrm{P}^{*}$} \\
\hline & $\begin{array}{l}\text { Deficient } \\
\text { (<20 ng/mL) }\end{array}$ & $\begin{array}{l}\text { Insufficient } \\
(20-29.99 \mathrm{ng} / \mathrm{mL})\end{array}$ & $\begin{array}{l}\text { Sufficient } \\
\text { ( } \geq 30 \mathrm{ng} / \mathrm{mL})\end{array}$ & \\
\hline Wearing clothes which restrict exposure to sunlight & & & & $p=0.032$ \\
\hline Yes & $77.2 \%$ & $14.6 \%$ & $8.3 \%$ & \\
\hline No & $71.3 \%$ & $11.5 \%$ & $17.2 \%$ & \\
\hline Sunlight exposure & & & & $p=0.570$ \\
\hline$<8$ points & $82.4 \%$ & $11.8 \%$ & $5.9 \%$ & \\
\hline 8-11 points & $78.2 \%$ & $10.9 \%$ & $10.9 \%$ & \\
\hline$\geq 12$ points & $71.8 \%$ & $15.9 \%$ & $12.3 \%$ & \\
\hline Daily calcium intake & & & & $p=0.880$ \\
\hline $500 \mathrm{mg} /$ day & $76.0 \%$ & $14.7 \%$ & $9.3 \%$ & \\
\hline$<500$ mg/day & $74.8 \%$ & $13.9 \%$ & $11.3 \%$ & \\
\hline
\end{tabular}

${ }^{*}$ Chi-square test.

Vitamin D is recognized as the sunshine vitamin. Skin synthesis of vitamin D is the major source of this vitamin. More than $90 \%$ of the vitamin D requirement for most people comes from casual exposure to sunlight. Natural dietary sources of vitamin D are limited, unless fortification or supplementation practices are adopted $[34,35]$. Regular sunlight exposure acts as effective prophylactic to prevent vitamin D deficiency. But even in Middle Eastern populations, who live in sunny climates, vitamin D deficiency is present in $50-97 \%$ of those tested $[32,36,37]$, most probably due to wearing of clothes which leave little skin exposed to sunlight. Our population also had a high percentage $(67.6 \%)$ who wore clothing which restricted sunlight exposure; this proportion was higher among women than among men. Overall sun exposure was also low in our population, with only $51.7 \%$ reporting a high degree of sun exposure, men having more sunlight exposure than women. Although our method for measuring skin exposure to sunlight was not objective, as in $\mathrm{cm}^{2}$ exposed, we feel that classification of the clothing habits of our population was a reasonable proxy for this variable.

As expected, we found a higher prevalence of vitamin D deficiency and insufficiency among those with less exposure to sunlight due to their clothing habits. However, the degree of overall sun exposure was not predictive of vitamin D status. We can not explain exactly why urban participants were more than two times likely

Table 4 Logistic regression models regarding 25(OH)D levels, with the following independent variables: sex (male/ female), age ( $<50 / \geq 50$ years), wearing of clothing which limits sunlight exposure (yes/no), and household location (urban/semiurban/rural)

\begin{tabular}{|c|c|c|c|c|}
\hline & $\begin{array}{l}\text { Model I: (vitamin D deficiency or } \\
\text { insufficiency vs sufficiency) }\end{array}$ & & Model II: (vitamin D deficiency vs sufficiency) & \\
\hline & Odds ratio $(95 \% \mathrm{Cl})$ & $p$ value & Odds ratio $(95 \% \mathrm{Cl})$ & $p$ value \\
\hline \multicolumn{5}{|l|}{ Age (years) } \\
\hline$<50$ (reference) & 1 & & 1 & \\
\hline$\geq 50$ & $0.55(0.28-1.09)$ & 0.090 & $0.56(0.28-1.13)$ & 0.107 \\
\hline \multicolumn{5}{|l|}{ Gender } \\
\hline Male (reference) & 1 & & 1 & \\
\hline Female & $1.28(0.63-2.57)$ & 0.484 & $1.47(0.72-3.00)$ & 0.282 \\
\hline \multicolumn{5}{|c|}{$\begin{array}{l}\text { Wearing clothes which restrict } \\
\text { exposure to sunlight }\end{array}$} \\
\hline Yes & $2.90(1.45-5.81)$ & 0.003 & $2.63(1.31-5.28)$ & 0.006 \\
\hline No (reference) & 1 & & 1 & \\
\hline \multicolumn{5}{|l|}{ Area of residence } \\
\hline Semiurban (reference) & 1 & & 1 & \\
\hline Urban & $2.47(1.17-5.21)$ & 0.017 & $2.42(1.14-5.12)$ & 0.020 \\
\hline Rural & $4.13(0.91-18.58)$ & 0.064 & $4.19(0.93-18.91)$ & 0.062 \\
\hline$r^{2}$ & 0.091 & & 0.098 & \\
\hline
\end{tabular}


to have vitamin D deficiency or insufficiency than those residing in semiurban areas. Tropospheric ozone is a common pollutant in central urban areas and may reduce synthesis of vitamin $D$ in the skin; this may then result in vitamin D deficiency [22]. However, in our population, the differences in prevalence of vitamin $\mathrm{D}$ deficiency are likely due to traditional dress in rural areas allowing less sunlight exposure to the skin.

This first randomly selected population-based survey indicates that vitamin $\mathrm{D}$ deficiency is very prevalent in the Aegean region of Turkey. Our results reflect those of the population living in one city and its surroundings; these results may differ markedly from those in other regions due to differences in climate, dress, nutrition, and sociodemographics. For this reason, a populationbased study of vitamin D status should be performed throughout Turkey as a whole.

\section{Limitations}

Several limitations were present in our study. First, only $70 \%$ of our randomly chosen households were available and agreed to be interviewed. Those refusing interviews, or those not at home, might have different vitamin D status than those at home, or those consenting to interviews. A greater number of our participants than planned were from the semiurban area, thus our results are reflective of this bias. Another issue facing our researchers was the presence of women, not men, in the homes during working hours, leading to $69.6 \%$ of our participants being female. Because women were overrepresented in our population sample, the overall mean $25(\mathrm{OH}) \mathrm{D}$ level would probably have been slightly higher if more men had been sampled. The fact remains though that only about $10 \%$ of men and women in the Aegean region of Turkey have an adequate vitamin D status.

Another limitation is one present in many surveys, that of taking a dietary history by survey instead of by direct observation or daily diary. Participants may not have given accurate information regarding their calcium intake.

Because this was a cross-sectional study, the reason for low vitamin D levels cannot be proved, only an association with lifestyle and dietary factors can be shown. A carefully performed longitudinal study would be required to examine causation of vitamin $D$ deficiency.

\section{Conclusion}

This population-based survey of households in the Aegean region of Turkey indicates that vitamin D deficiency is very prevalent. A nationwide population-based study is needed to determine the vitamin D status of persons in different locales throughout Turkey. Based on responses of our participants, lifestyle changes to increase sunlight exposure would increase vitamin D levels. A broad-based effort to prevent vitamin D deficiency in Turkey should be undertaken.

\section{Acknowledgements}

This work was supported by Celal Bayar University Research Foundation (grant number 2006-113).

\section{Author details}

${ }^{1}$ Celal Bayar University Medical Faculty, Department of Internal Medicine, Division of Endocrinology and Metabolism, Manisa, Turkey. ${ }^{2}$ Celal Bayar University Medical Faculty, Department of Public Health, Manisa, Turkey. ${ }^{3}$ Celal Bayar University Medical Faculty, Department of Clinical Biochemistry, Manisa, Turkey. ${ }^{4}$ Celal Bayar University, Vocational School of Health Services, Department of Biochemistry, Manisa, Turkey. ${ }^{5}$ Ministry of Health, Directorate General of Health for Border and Coastal Areas, Izmir, Turkey.

\section{Authors' contributions}

All authors contributed to the concept, design, analysis, interpretation of data, and preparation of the manuscript. All authors read and approved the final manuscript.

\section{Competing interests}

The authors declare that they have no competing interests.

Received: 11 June 2010 Accepted: 23 December 2010

Published: 23 December 2010

\section{References}

1. Holick MF: Vitamin D deficiency. N Engl J Med 2007, 357:266-281.

2. Holick MF: Resurrection of vitamin D deficiency and rickets. J Clin Invest 2006, 116:2062-2072.

3. Holick MF, Chen TC: Vitamin D deficiency: a worldwide problem with health cosequences. Am J Clin Nutr 2008, 87:1080S-1086S.

4. Bordelon P, Ghetu MV, Langan R: Recognition and management of vitamin D deficiency. Am Fam Physician 2009, 80:841-846.

5. Holick MF: High prevalence of vitamin D inadequacy and implications for health. Mayo Clin Proc 2006, 81:353-373.

6. Lee JH, O'Keefe JH, Bell D, Hensrud DD, Holick MF: Vitamin D deficiency an important, common, and easily treatable cardiovascular risk factor? J Am Coll Cardiol 2008, 52:1949-1956.

7. Kanekar A, Sharma M, Joshi VR: Vitamin D deficiency-a clinical spectrum: is there a symptomatic nonosteomalacic state? Int J Endocrinol 2010, 2010:521457.

8. Kulie T, Groff A, Redmer J, Hounshell J, Schrager S: Vitamin D: an evidencebased review. J Am Board Fam Med 2009, 22:698-706.

9. Lips P: Vitamin D deficiency and secondary hyperparathyroidism in the elderly: consequences for bone loss and fractures and therapeutic implications. Endocr Rev 2001, 22:477-501.

10. Lips P: Vitamin D status and nutrition in Europe and Asia. J Steroid Biochem Mol Biol 2007, 103:620-625.

11. Chiu KC, Chu A, Go VL, Saad MF: Hypovitaminosis D is associated with insulin resistance and $\beta$ cell dysfunction. Am J Clin Nutr 2004, 79:820-825.

12. Hyppönen $E$, Läärä $E$, Reunanen $A$, Järvelin MR, Virtanen SM: Intake of vitamin D and risk of type 1 diabetes: a birthcohort study. Lancet 2001, 358:1500-1503.

13. Pittas AG, Dawson-Hughes B, Li T, Van Dam RM, Willett WC, Manson JE, Hu FB: Vitamin D and calcium intake in relation to type 2 diabetes in women. Diabetes Care 2006, 29:650-656.

14. Gorham ED, Garland CF, Garland FC, Grant WB, Mohr SB, Lipkin M, Newmark HL, Giovannucci E, Wei M, Holick MF: Vitamin D and prevention of colorectal cancer. J Steroid Biochem Mol Biol 2005, 97:179-194.

15. Holick MF: Calcium plus vitamin D and the risk of colorectal cancer. $N$ Engl J Med 2006, 354:2287-2288.

16. Gorham ED, Garland CF, Garland FC, Grant WB, Mohr SB, Lipkin M, Newmark HL, Giovannucci E, Wei M, Holick MF: Optimal vitamin D status for colorectal cancer prevention: a quantitative meta analysis. American Journal of Preventive Medicine 2007, 32:210-216. 
17. Garland CF, Garland FC, Gorham ED, Lipkin M, Newmark H, Mohr SB, Holick MF: The role of vitamin D in cancer prevention. Am J Public Health 2006, 96:252-261.

18. VanAmerongen BM, Dijkstra CD, Lips P, Polman CH: Multiple sclerosis and vitamin D: an update. Eur J Clin Nutr 2004, 58:1095-1109.

19. Munger KL, Levin LI, Hollis BW, Howard NS, Ascherio A: Serum 25hydroxyvitamin D levels and risk of multiple sclerosis. JAMA 2006, 296:2832-2838.

20. Cantorna MT, Zhu Y, Froicu M, Wittke A: Vitamin D status, 1,25dihydroxyvitamin D3, and the immune system. Am J Clin Nutr 2004, 80(Suppl 6):1717S-1720S.

21. White JH: Vitamin D signaling, infectious diseases, and regulation of innate immunity. Infect Immun 2008, 76:3837-3843.

22. Manicourt DH, Devogelaer JP: Urban tropospheric ozone increases the prevalence of vitamin $D$ deficiency among Belgian postmenopausal women with outdoor activities during summer. J Clin Endocrinol Me tab 2008, 93:3893-3899.

23. Atli T, Gullu S, Uysal AR, Erdogan G: The prevalence of vitamin D deficiency and effects of ultraviolet light on vitamin $D$ levels in elderly Turkish population. Arch Gerontol Geriatr 2005, 40:53-60.

24. Alagöl F, Shihadeh Y, Boztepe H, Tanakol R, Yarman S, Azizlerli H, Sandalci O: Sunlight exposure and vitamin D deficiency in Turkish women. J Endocrinol Invest 2000, 23:173-177.

25. Guzel R, Kozanoglu E, Guler-Uysal F, Soyupak S, Sarpel T: Vitamin D status and bone mineral density of veiled and unveiled Turkish women. J Womens Health Gend Based Med 2001, 10:765-770.

26. Erkal MZ, Wilde J, Bilgin $Y$, Akinci A, Demir E, Bödeker RH, Mann M, Bretzel RG, Stracke H, Holick MF: High prevalence of vitamin D deficiency, secondary hyperparathyroidism and generalized bone pain in Turkish immigrants in Germany: identification of risk factors. Osteoporos Int 2006, 17:1133-1140.

27. Manisa Province Health Directorate, Manisa Annual Health Statistics 2005, Manisa Yedikardesler ofset. 2006.

28. Looker AC, Dawson-Hughes B, Calvo MS, Gunter EW, Sahyoun NR: Serum 25-hydroxyvitamin $D$ status of adolescents and adults in two seasonal subpopulations from NHANES III. Bone 2002, 30:771-777.

29. Van der Wielen RP, Löwik MR, van den Berg H, de Groot LC, Haller J, Moreiras O, van Staveren WA: Serum vitamin D concentrations among elderly people in Europe. Lancet 1995, 346:207-210.

30. Hyppönen $E$, Power $C$ : Hypovitaminosis D in British adults at age $45 \mathrm{y}$ : nationwide cohort study of dietary and lifestyle predictors. Am J Clin Nutr 2007, 85:860-868.

31. Levis S, Gomez A, Jimenez C, Veras L, Ma F, Lai S, Hollis B, Roos BA: Vitamin $D$ deficiency and seasonal variation in an adult South Florida population. J Clin Endocrinol Me tab 2005, 90:1557-1562.

32. Meddeb N, Sahli H, Chahed M, Abdelmoula J, Feki M, Salah H, Frini S, Kaabachi N, Belkahia Ch, Mbazaa R, Zouari B, Sellami S: Vitamin D deficiency in Tunisia. Osteoporos Int 2005, 16:180-183.

33. Kull M Jr, Kallikorm R, Tamm A, Lember M: Seasonal variance of 25-(OH) vitamin $D$ in the general population of Estonia, a Northern European country. BMC Public Health 2009, 9:22.

34. Holick MF: Sunlight and vitamin D for bone health and prevention of autoimmune diseases, cancers, and cardiovascular disease. Am J Clin Nutr 2004, 80(6 Suppl):1678S-1688S.

35. Heaney RP: Long-latency deficiency disease: insights from calcium and vitamin D. Am J Clin Nutr 2003, 78:912-919.

36. Matsuoka LY, Wortsman J, Dannenberg MJ, Hollis BW, Lu Z, Holick MF: Clothing prevents ultraviolet- $B$ radiation-dependent photosynthesis of vitamin D3. J Clin Endocrinol Me tab 1992, 75:1099-1103.

37. Mishal AA: Effects of different dress styles on vitamin D levels in healthy young Jordanian women. Osteoporos Int 2001, 12:931-935.

\section{Pre-publication history}

The pre-publication history for this paper can be accessed here: http://www.biomedcentral.com/1471-2458/10/782/prepub

doi:10.1186/1471-2458-10-782

Cite this article as: Hekimsoy et al: Vitamin D status among adults in the Aegean region of Turkey. BMC Public Health 2010 10:782.

\section{Submit your next manuscript to BioMed Central and take full advantage of:}

- Convenient online submission

- Thorough peer review

- No space constraints or color figure charges

- Immediate publication on acceptance

- Inclusion in PubMed, CAS, Scopus and Google Scholar

- Research which is freely available for redistribution

Submit your manuscript at www.biomedcentral.com/submit 